\title{
MEDIA PEMBELAJARAN POP-UP BOX SIMULASI MYOB ACCOUNTING PADA MATA PELAJARAN KOMPUTER AKUNTANSI
}

\section{LEARNING MEDIA POP-UP BOX MYOB ACCOUNTING SIMULATION ON ACCOUNTING COMPUTER COURSE}

\author{
Oleh: \\ Denisa Nugrah Anggraeni \\ Prodi Pendidikan Akuntansi Universitas Negeri Yogyakarta \\ denisanugrah58@gmail.com
}

$\underline{\text { Sukirno }}$

Staf Pengajar Jurusan Pendidikan Akuntansi Universitas Negeri Yogyakarta

\begin{abstract}
Abstrak
Media dalam pembelajaran dinilai penting untuk menarik perhatian siswa dalam memahami isi pelajaran yang berkaitan dengan makna visual. Penelitian pengembangan media pembelajaran ini bertujuan untuk mengembangan media pembelajaran Pop-up Box Simulasi MYOB Accounting pada mata pelajaran komputer akuntansi untuk siswa kelas XII Akuntansi 1 SMK Negeri 1 Bawang Banjarnegara, menghasilkan media pembelajaran Pop-up Box Simulasi MYOB Accounting pada mata pelajaran komputer akuntansi yang layak berdasarkan penilaian ahli materi, ahli media, dan praktisi pembelajaran akuntansi, serta mengetahui penilaian siswa terhadap media pembelajaran Pop-up Box Simulasi $M Y O B$ Accounting. Penelitian ini merupakan jenis penelitian dan pengembangan (Research and Development). Hasil penelitian menunjukkan bahwa media pembelajaran Pop-up Box Simulasi $M Y O B$ Accounting dikembangkan melalui 5 tahapan yaitu analysis, design, development, implementation, dan evaluation. Media Pop-up Box Simulasi MYOB Accounting layak digunakan sebagai media pembelajaran berdasarkan penilaian dari ahli materi diperoleh persentase kualitas kelayakan media sebesar 90,53\% yang termasuk dalam kategori sangat layak, ahli media diperoleh persentase kualitas kelayakan media sebesar $91,25 \%$ yang termasuk dalam kategori sangat layak, dan praktisi pembelajaran akuntansi diperoleh persentase kualitas kelayakan media sebesar 83,81\% yang termasuk dalam kategori sangat layak. Selanjutnya untuk penilaian siswa kelas XII Akuntansi 1 diperoleh persentase kualitas kelayakan media sebesar 94,67\% yang termasuk dalam kategori sangat layak.
\end{abstract}

Kata Kunci: Media Pembelajaran, Komputer Akuntansi, ADDIE, Pop-up Box, MYOB Accounting.

\begin{abstract}
The media in learning is considered important to attract students attention in understanding the content of the lessons related to visual meaning. This research aimed to develop Learning Media Pop-up Box MYOB Accounting Simulation on Accounting Computer Material for class XII Accounting 1 in SMK Negeri 1 Bawang Banjarnegara, produce learning media of Pop-up Box MYOB Accounting Simulation on accounting computer material feasible based on evaluation by subject experts, media experts, and accounting learning practitioners, and determine student's the evaluation of learning media Pop-up Box MYOB Accounting Simulation. This research is a type of research and development (Research and Development). The results showed learning media Pop-up Box MYOB Accounting Simulation was developed through 5 stages, they were analysis, design, development, implementation, and evaluation. Media Pop-up Box MYOB Accounting Simulation is worthy of being used as a learning media based on assessment subjects experts gave $90.53 \%$ which is categorized into very feasible
\end{abstract}


category, media experts gave $91,25 \%$ which is categorized into very feasible category and accounting learning practitioners gave $83.81 \%$ which is categorized into very feasible category. Futhermore, for student assesment showed 94,67 which is categorized into very feasible category.

Keywords: Learning Media, Accounting Computer, ADDIE, Pop-up Box, MYOB Accounting.

\section{PENDAHULUAN}

Pada saat ini kebutuhan akan adanya ilmu pengetahuan dan teknologi yang selalu berkembang dan berubah telah menjadi tantangan bagi guru dalam dunia pendidikan. Penggunaan media pembelajaran tersebut yang menjadi tantangan bagi dunia pendidikan. Adanya tantangan tersebut, maka setiap orang harus mampu beradaptasi dengan kemajuan ilmu pengetahuan dan teknologi guna mencetak sumber daya manusia yang berkualitas tinggi. Proses pembelajaran dapat berjalan dengan baik apabila tujuan pendidikan nasional tercapai dan guru bisa menjadi fasilitator para siswa untuk mengembangkan kemampuan serta potensi pada diri siswa. Namun pada kenyataannya, dalam proses pembelajaran yang dikembangkan guru di Indonesia masih tergolong lemah. Seperti guru kesulitan memanfaatkan dan mengembangkan media pembelajaran yang sesuai dengan kompetensi dasar yang harus dicapai siswa (Dwikoranto, 2009: 313) serta guru belum memanfaatkan secara optimal empat pilar pembelajaran seperti learning to know, learning to do, learning to be dan learning to live together (Octoria, 2015: 323). Pada umumnya guru masih menggunakan komunikasi satu arah sehingga tidak berusaha mengajak siswa untuk berpikir. Guru hanya mengajar dengan model ceramah dan latihan saja. Apabila kondisi tersebut sering terjadi, tujuan pendidikan nasional tidak tercapai dengan baik. Guru dapat menghindari permasalahan tersebut dengan menyusun strategi pembelajaran melalui pemanfaatan berbagai media dan sumber belajar. Menurut Sadiman (2014: 3) guru memang bukan satu-satunya sumber belajar, walaupun tugas, peranan dan fungsinya dalam proses belajar mengajar sangat penting.
Dalam proses belajar mengajar, tidak selamanya guru membawa siswa ke objek atau peristiwa dan sebaliknya. Guru dapat melakukan proses belajar mengajar secara tidak langsung, yakni siswa secara aktif berinteraksi dengan media. Menurut Sadiman (2014: 7) media merupakan segala sesuatu yang digunakan untuk menyalurkan pesan dari pengirim ke penerima sehingga dapat merangsang pikiran perasaan perhatian dan minat serta perhatian siswa sedemikian rupa sehingga proses belajar terjadi. Peran media pembelajaran merupakan salah satu upaya untuk meningkatkan proses interaksi maupun komunikasi antara guru dengan siswa serta interaksi antara siswa dengan lingkungan belajarnya. Menurut Sadiman (2014: 17) penggunaan media pendidikan secara bervariasi dan tepat dapat mengatasi sikap pasif anak didik. Dalam membuat suatu media, karakteristik siswa dan metode pembelajaran merupakan bahan dasar yang harus disesuaikan oleh guru. Menurut Sudjana \& Rivai (2011: 4-5) dalam memilih media pembelajaran sebaiknya memperhatikan kriteria-kriteria seperti ketepatan dengan tujuan pengajaran, dukungan terhadap isi bahan pelajaran, kemudahan memperoleh media, keterampilan guru dalam menggunakannya, tersedia waktu untuk menggunakannya, dan sesuai dengan taraf berfikir siswa.

Jenis media pembelajaran yang dapat digunakan oleh guru adalah media visual yang berunsur 3 dimensi (3D). Menurut Numtahanah (2014) kelebihan media visual sebagai media pembelajaran dalam proses belajar siswa, antara lain (1) Media visual dapat mengatasi keterbatasan yang dimiliki peserta didik seperti ketersediaan buku (2) Meningkatkan daya tarik dan perhatian siswa dan (3) Siswa akan melakukan 
aktivitas, karena siswa tidak hanya mendengarkan tetapi juga dapat mengamati, mendemonstrasikan, dan memerankannya. Dengan adanya media visual sebagai media pembelajaran maka dapat memperlancar pemahaman siswa terhadap materi, memperkuat ingatan, meningkatkan daya tarik siswa dalam belajar dan melibatkan interaksi dalam proses pembelajaran (Arsyad, 2015: 89).

SMK Negeri 1 Bawang Banjarnegara merupakan salah satu sekolah kejuruan yang sudah menerapkan K13 revisi pada semua progam keahlian, seperti progam keahlian akuntansi dan lembaga keuangan pada mata pelajaran komputer akuntansi. Mata pelajaran komputer akuntansi merupakan mata pelajaran kejuruan di kelas XII Akuntansi. Dalam pembelajaran, penggunaan progam komputer akuntansi sebagai pendukung dalam bidang akuntansi merupakan kebutuhan yang mutlak. Salah satu progam aplikasi akuntansi yang didesain untuk memenuhi kebutuhan penyediaan informasi akuntansi adalah Mind Your Own Business (MYOB). Menurut Maulidah (2011) hampir semua lembaga pendidikan di tingkat SMK pada kompetensi keahlian akuntansi mengajarkan pratikum komputerisasi secara manual dilengkapi dengan pratikum komputerisasinya dengan aplikasi $M Y O B$. Hal ini dikarenakan salah satu ketrampilan yang diberikan di SMK kompetensi keahlian akuntansi yang berbasis komputer adalah komputer akuntansi Mind Your Own Business (MYOB).

Berdasarkan hasil wawancara yang dilakukan peneliti dengan salah satu siswa kelas XII Akuntansi menyebutkan bahwa saat proses pembelajaran di kelas guru masih menggunakan metode konvensional dalam mengajar dengan bantuan buku paket, modul, e-book dan latihan soal sebagai bahan ajarnya. Dengan hal ini guru masih menggunakan pilar learning to know dan learning to do saja sehingga belum memanfaatkan pilar learning to be dan learning to live together. Hal ini didukung dengan hasil observasi melalui angket yang dilakukan peneliti diperoleh bahwa 100\% siswa menyebutkan bahwa pembelajaran dikelas menggunakan buku paket, modul, $e$ book dan latihan soal sebagai bahan ajar. Meskipun dalam pembelajaran komputer akuntansi MYOB terdapat sebuah praktik yang menggunakan media pendukung komputer. Tetapi siswa sifatnya hanya mempraktikan apa yang dipaparkan oleh guru melalui modul dan siswa hanya melihat panduan cara mengerjakannya melalui modul, sehingga mereka akan mudah lupa apa yang dipelajari. Dengan demikian, siswa terlihat bosan dalam mengikuti pembelajaran ditunjukkan dengan kurang antusiasnya siswa dalam menyimak materi dan kurang inovatifnya guru dalam penyampaian materi. Siswa menyatakan bahwa $100 \%$ mereka membutuhkan metode mengajar lain untuk meningkatkan antusias mereka dalam belajar komputer akuntansi. Dalam meningkatkan antusias siswa dalam belajar komputer akuntansi $M Y O B$, salah satu media pembelajaran yang dapat dikembangkan adalah pop-up box. Berdasarkan observasi $94 \%$ siswa menyatakan bahwa siswa tertarik apabila pembelajaran komputer akuntansi didukung menggunakan media pop-up box. Media pop-up box ini disajikan dengan desain yang menarik perhatian siswa dalam proses pembelajaran. Sehingga diharapkan dapat meningkatkan antusias siswa pada mata pelajaran Komputer Akuntansi, mengurangi kesulitan pemahaman siswa dalam belajar, dan proses pembelajaran yang berlangsung dapat menyenangkan.

Pengembangan media pembelajaran pop-up box merupakan salah satu media pembelajaran berbentuk simulasi belajar. Pembelajaran simulasi mengarah pada pencapaian empat pilar pembelajaran yakni tidak hanya membuat siswa tau dan paham mengenai komputer akuntansi, tapi tujuan utamanya adalah penerapan ilmu pada kehidupan nyata. Penerapan ilmu ini 
diwujudkan dengan menghadirkan kondisi nyata ke dalam kegiatan belajar di kelas. Media pop-up box ini tidak hanya berupa teori saja namun terdapat soal latihan sebagai bentuk evaluasi siswa. Pop-up box terkenal dengan tampilan gambar yang memiliki dimensi, salah satu bagian dapat berubah bentuk apabila halamannya dibuka atau bagiannya digeser. Pop-up box mempunyai kemampuan untuk memperkuat pesan yang ingin disampaikan dalam sebuah pembelajaran sehingga materi lebih dipahami oleh siswa.

Penelitian yang dilakukan oleh Scolastika Mariani, dkk (2014) yang berjudul "The Effectiveness of Learning by PBL Assisted Mathematics Pop-Up Book Againts The Spatial Ability in Grade VIII on Geometry Subject Matter" menunjukkan bahwa Mathematics Pop Up Book is combination of student books and props mathematics. Pop-up book used at the stage of concept explanation and application of concepts through exercises. Overall the use of pop-up book done in groups. The result of questionnaire about Mathematics Pop Up Book is verry good. Hal ini berarti pop-up digunakan dengan konsep penjelasan, konsep latihan, dan dilakukan dalam kelompok hasilnya sangat bagus.

Penelitian ini sejalan dengan penelitian yang dilakukan oleh Septi Mahayani (2017) dengan hasil penelitian yang menyebutkan bahwa media pembelajaran berupa kotak pop-up sangat layak sebagai pemecah masalah dan sangat menarik untuk sumber pembelajaran.

Berdasarkan uraian diatas, maka peneliti tertarik melakukan penelitian dengan judul "Pengembangan Media Pembelajaran Pop-up Box Simulasi $M Y O B$ Accounting Pada Mata Pelajaran Komputer Akuntansi Untuk Siswa Kelas XII Akuntansi 1 SMKN 1 Bawang Banjarnegara Tahun Ajaran 2018/2019".

\section{METODE PENELITIAN}

Penelitian ini merupakan jenis penelitian dan pengembangan (Research and Development). Metode penelitian dan pengembangan merupakan metode yang digunakan untuk menghasilkan suatu produk tertentu dan menguji keefektifan produk tersebut (Sugiyono, 2016: 407).

Subjek dalam penelitian Pengembangan Media Pembelajaran Pop-up Box Simulasi $M Y O B$ Accounting adalah ahli materi, ahli media, praktisi pembelajaran Akuntansi dan siswa kelas XII Akuntansi 1 SMKN 1 Bawang Banjarnegara yang terdiri dari 36 siswa.

Pengembangan media pembelajaran Pop-up Box Simulasi MYOB Accounting merupakan adaptasi dari langkah-langkah penelitian pengembangan model ADDIE yang terdiri dari Analysis, Design, Development, Implementation, dan Evaluation. Mulyatiningsih (2012: 199) menjelaskan bahwa model ADDIE dapat digunakan untuk strategi pembelajaran, media, dan bahan ajar. Tahapan pengembangan media pembelajaran Pop-up Box Simulasi MYOB Accounting dengan model pengembangan $A D D I E$ adalah sebagai berikut.

1. Tahap Analisis (Analysis)

Pada tahap awal dilakukan analisis kebutuhan siswa kelas XII Akuntansi 1 SMKN 1 Bawang Banjarnegara guna mengetahui permasalahan yang dihadapi siswa dalam pembelajaran Komputer Akuntansi dan peneliti juga menganalisis Kompetensi Inti dan Kompetensi Dasar pada mata pelajaran Komputer Akuntansi. Media pembelajaran Pop-up Box Simulasi $M Y O B$ Accounting diharapkan mampu memenuhi kebutuhan siswa kelas XII Akuntansi 1 SMKN 1 Bawang Banjarnegara yakni tersedianya variasi media pembelajaran yang mampu mengatasi kesulitan siswa dalam belajar.

2. Tahap Desain (Design) 
Tahap desain merupakan tahap kedua dalam pengembangan ADDIE, peneliti mengumpulkan informasi yang menunjang pengembangan media pembelajaran yang akan dibuat. Hasil inforrmasi tersebut adalah:

a. Perancangan konsep desain media pembelajaran

Pada tahap ini peneliti mulai merancang desain produk yang sesuai dengan subjek penelitian dan materi tentang Komputer Akuntansi yang akan digunakan dalam Media Pembelajaran Pop-up Box Simulasi MYOB Accounting.

b. Penyusunan materi, soal, kunci jawaban, dan petunjuk penggunaan media

Pada tahap ini materi yang disusun adalah computer akuntansi perusahaan manufaktur, menyusun soal latihan, kunci jawaban, dan petunjuk penggunaan media yang akan dimuat dalam media pembelajaran.

c. Pembuatan desain media pembelajaran

Tahap ini pembuatan desain untuk Pop-up Box yang meliputi cover box, petunjuk penggunaan media dan cover buku sakti menggunaan aplikasi Photoshop dan CorelDraw X7. Kemudian untuk materi dan kartu soal menggunakan Microsoft Word.

3. Tahap Pengembangan (Development)

Tahap ketiga meliputi pembuatan produk, validasi ahli materri, validasi ahli media, dan validasi praktisi pembelajaran Akuntansi.

a. Membuat produk media pembelajaran Pop-up Box Simulasi $M Y O B$ Accounting

Berdasarkan desain yang telah dirancang, kemudian dilakukan pembuatan produk. Semua komponen tersebut yang telah dipersiapkan dirangkai menjadi satu menjadi produk Media Pembelajaran

Pop-up Box Simulasi MYOB Accounting.

b. Validasi

Pada tahap ini media divalidasi oleh beberapa ahli seperti ahli media, ahli materi dan praktisi pembelajaran akuntansi SMKN 1 Bawang Banjarnegara. Hasil dari validasi tersebut berupa saran, komentar, dan masukan yang digunakan sebagai dasar untuk melakukan revisi terhadap media yang dikembangkan.

4. Tahap Implementasi (Implementation)

a. Uji coba kelompok kecil

Uji coba kelompok kecil dilakukan pada 16 siswa kelas XII Akuntansi 3 SMKN 1 Bawang Banjarnegara. Dalam uji coba ini peneliti memantau jalannya kegiatan selama media pembelajaran digunakan siswa. Tahap ini juga peneliti membagikan angket untuk mengetahui penilaian siswa terhadap produk yang dikembangkan.

b. Uji coba lapangan

Pada tahap ini uji coba dilakukan pada 36 siswa kelas XII Akuntansi 1 SMKN 1 Bawang Banjarnegara. Pada tahap ini juga peneliti membagikan angket untuk mengetahui penilaian siswa terhadap produk yang dikembangkan.

5. Tahap Evaluasi (Evaluation)

Tahap kelima, peneliti melakukan evaluasi untuk mengukur keberhasilan tujuan pengembangan produk Media Pembelajaran Pop-up Box Simulasi $M Y O B$ Accounting yaitu analisis hasil kelayakan produk akhir pada mata pelajaran Komputer Akuntansi dan membandingkan hasil yang didapatkan pada setiap tahapan penilaian kelayakan produk media pembelajaran tersebut.

Data yang dikumpulkan dalam penelitian ini merupakan data kuantitatif yang berupa pendapat mengenai penilaian kelayakan tentang media pembelajaran 
Teknik pengumpulan data yang digunakan berupa angket. Menurut Sugiyono (2016: 199) angket dapat berupa pertanyaan tertutup atau terbuka. Angket ini digunakan untuk memperoleh data dari ahli media, ahli materi, praktisi pembelajaran Akuntansi, dan siswa sebagai bahan evaluasi media pembelajaran yang dikembangkan oleh peneliti.

Penelitian ini menggunakan teknik analisis kuantitatif dengan data yang diperoleh dari validator. Kemudian data tersebut dianalisis secara deskriptif kualitatif dan dijadikan sebagai dasar acuan dalam merevisi produk agar diperoleh produk yang layak. Suatu produk yang dikembangkan dapat dinilai menggunakan Skala Likert.

\section{Tabel 1. Ketentuan Pemberian Nilai}

\begin{tabular}{|l|c|}
\hline \multicolumn{1}{|c|}{ Kategori } & Nilai \\
\hline (SL) Sangat Layak & 5 \\
\hline (L) Layak & 4 \\
\hline (CL) Cukup Layak & 3 \\
\hline (KL)Kurang Layak & 2 \\
\hline (TL) Tidak Layak & 1 \\
\hline
\end{tabular}

Sumber: Widoyoko (2012: 107)

Setelah data yang terkumpul, kemudian untuk melihat bobot masing-masing aspek dengan menghitung skor rerata menggunakan rumus sebagai berikut.

$$
\bar{x}=\frac{\sum x}{n}
$$

Sumber: Ernawati \& Sukardiyono (2017: 207)

Keterangan:

$\bar{x}=$ skor rata-rata

$\mathrm{n}=$ jumlah penilai

$\sum \mathrm{x}=$ jumlah total masing-masing

Menjumlahkan rerata skor setiap aspek, selanjutnya jumlah rerata skor tiap aspek diinterpretasikan secara kualitatif ke dalam nilai dan klasifikasi dengan lima kategori yakni:

Tabel 2. Pedoman Konversi Skor Hasil Penilaian Kedalam Nilai dan Klasifikasi dengan Lima Kategori

\begin{tabular}{|c|c|}
\hline $\begin{array}{c}\text { Rerata Skor } \\
\text { Jawaban }\end{array}$ & Klasifikasi \\
\hline
\end{tabular}

Persentase Total skor yang diperoleh Hasil Skor maksimum

\begin{tabular}{|c|c|}
\hline$>4,2-5,0$ & Sangat Layak \\
\hline$>3,4-4,2$ & Layak \\
\hline$>2,6-3,4$ & Cukup Layak \\
\hline$>1,8-2,6$ & Kurang Layak \\
\hline $1,0-1,8$ & Tidak Layak \\
\hline
\end{tabular}

Sumber: Widoyoko (2012: 112)

Kemudian untuk menghitung presentase tingkat penilaian dengan rumus sebagai berikut:

Sumber: Ernawati \& Sukardiyono (2017: 207)

Berdasarkan perhitungan diatas, maka kategori kelayakan berdasarkan kriteria sebagai berikut.

Tabel 3. Kategori Penilaian Kualitas Media Pembelajaran

\begin{tabular}{|c|c|c|}
\hline No & $\begin{array}{c}\text { Skor Persentase } \\
(\mathbf{\%})\end{array}$ & $\begin{array}{c}\text { Kategori } \\
\text { Kelayakan }\end{array}$ \\
\hline 1 & $81-100 \%$ & Sangat Layak \\
\hline 2 & $61-80 \%$ & Layak \\
\hline 3 & $41-60 \%$ & Cukup Layak \\
\hline 4 & $21-40 \%$ & Kurang Layak \\
\hline 5 & $<21 \%$ & Tidak Layak \\
\hline
\end{tabular}

Sumber: Ernawati \& Sukardiyono (2017: 207)

\section{HASIL PENELITIAN DAN PEMBAHASAN}

\section{Hasil Penelitian Pengembangan Media Pembelajaran Pop-up Box Simulasi MYOB Accounting}

Pengembangan Media Pembelajaran Pop-up Box Simulasi MYOB Accounting merupakan adaptasi dari langkah-langkah penelitian pengembangan model ADDIE yakni tahapannya seperti 1) analysis 2) design 3) development 4) implementation 5) evaluation. Penjabaran dari langkah-langkah pengembangan tersebut adalah sebagai berikut.

1. Tahap Analisis (Analysis) 
Berdasarkan hasil wawancara dengan siswa dan guru mengenai pembelajaran Komputer Akuntansi, pembelajaran tersebut masih menggunakan metode konvensional dengan berbantuan buku paket, modul atau $e$-book sebagai bahan ajarnya dan guru belum memanfaatkan media pembelajaran dalam pembelajaran di kelas. Sehingga, pembelajaran tersebut cenderung monoton dan mengakibatkan siswa mudah bosan. Hal tersebut mengakibatkan kurang antusiasnya siswa dalam mempelajari Komputer Akuntansi dan kurang inovatifnya guru dalam penyampaian materi Komputer Akuntansi. Selain itu, peneliti juga menganalisis Kompetensi Inti dan Kompetensi dasar mata pelajaran Komputer Akuntansi yang sedang diampu oleh siswa.

2. Tahap Desain (Design)

Pada tahap kedua dalam pengembangan ADDIE, peneliti mengumpulkan informasi yang menunjang pengembangan media pembelajaran yang akan dibuat. Hasil yaitu konsep desain media pembelajaran Pop-up Box Simulasi $M Y O B$ Accounting yang terinspirasi dari banyaknya di social media yang menjual Pop-up Box. Namun, pada media Pop-up Box Simulasi $M Y O B$ Accounting ini terdapat beberapa modifikasi seperti desain Pop-up Box, miniatur rumah yang terdapat di tengah box dengan terdapat roll soal kasus dibagian atas rumah, tambahan kartukartu disamping rumah yang memuat kartu-kartu transaksi dan kunci jawaban mengenai materi Komputer Akuntansi serta empat sisi box yang berisi paket soal mengenai Komputer Akuntansi beserta materi Komputer Akuntansi yang berbentuk seperti buku saku. Kartu-kartu tersebut memiliki warna yang berbeda-beda dengan arti yang berbeda. Selanjutnya yaitu penyusunan materi, soal, kunci jwaban, dan petunjuk penggunaan media. Pada penggunaan media Pop-up Box Simulasi $M Y O B$ Accounting siswa membentuk kelompok yang terdiri dari empat siswa, kemudian duduk secara berkelompok dengan masing-masing kelompok menggunakan satu computer didepannya. Setelah itu, siswa membuka media pembelajaran tersebut. Di dalam media tersebut terdapat empat buah buku saku untuk tiap anggota kelompoknya. Tiap kelompok membagi tugasnya masing-masing yakni dua orang menganalisis transaksi dan dua orang menginput transaksi tersebut ke dalam komputer sebagai media pendukung dalam pembelajaran Komputer Akuntansi. Dalam media pembelajaran ini terdapat dua macam soal yakni soal teori dan soal praktik. Tiap siswa mendapatkan soal teori yang berbeda dan mendapatkan soal praktik yang sama sehingga harus diselesaikan secara bersama-sama. Soal praktik bisa siswa baca dengan cara menarik papan roll yang terdapat diatas atas sebuah miniature perusahaan. Selanjutnya, untuk mengerjakan soal tersebut membutuhkan kartu-kartu seperti kartu persediaan, kartu utang, kartu piutang, kartu perlengkapan, kartu peralatan, kartu transaksi, dan kunci jawaban sebagai pelengkap soal praktik tersebut dengan mengambil di sisi samping miniatur perusahaan. Sebelum mengerjakan soal teori dan praktik, siswa bisa mempelajari materinya terlebih dahulu dengan membaca buku saku yang terdapat dalam media tersebut. Pembuatan desain cover dan layout dalam Pop-up Box menggunakan aplikasi Photoshop dan CorelDraw X7 yang berasal dari vector dikonversikan ke dalam bitmap. Selain itu, pembuatan kartu-kartu nya menggunakan aplikasi Microsoft Word. Produk ini didesain semenarik mungkin agar siswa antusias 
dalam mengikuti pembelajaran Komputer Akuntansi dan tercipta kesan yang baik pada siswa. Kelengkapan Pop-up Box Simulasi $M Y O B$ Accounting yaitu 1 buah media Pop-up Box Simulasi MYOB Accounting, 1 set kartu warna biru muda (5 buah kartu transaksi kas masuk), 1 set kartu warna merah muda ( 6 buah kartu transaksi kas keluar), 1 set kartu warna coklat muda (12 buah kartu bukti memorial), 1 set kartu warna hijau muda (2 buah kartu faktur pembelian), 1 set kartu warna oren ( 2 buah kartu faktur penjualan), 1 set kartu warna ungu muda (3 buah kartu transaksi kas kecil), 1 set warna kuning (10 buah kartu pelengkap yang terdiri dari kartu utang, kartu piutang, kartu perlengkapan, kartu peralatan, kartu persediaan), dan 1 set warna putih (7 buah kunci jawaban).

3. Tahap Pengembangan (Development)

Pada tahap pengembangan peneliti memperoleh hasil yang pertama adalah pembuatan produk yaitu menggabungkan seluruh komponen yang sudah melalui tahap desain. Rincian harga semua komponen media adalah sebagai berikut.

\begin{tabular}{|c|c|c|}
\hline Bahan akrilik & @4buah & Rp708.600 \\
\hline $\begin{array}{l}\text { Print kertas } \\
\text { @ 46lembar }\end{array}$ & ivory 310 & Rp117.500 \\
\hline $\begin{array}{l}\text { Print kertas } \\
\text { @ } 5 \text { lembar }\end{array}$ & ivory 230 & Rp $\quad 9.000$ \\
\hline
\end{tabular}

Kertas Hvs $\quad$ 80gr Rp166.400 @64lembar

Kertas warna ivory $210 \quad \mathrm{Rp} 37.400$ @22lembar

Print stiker cromo Rp 70.000 @14lembar

Jilid binding

Laminasi glossy Jumlah

Rp200.000

Rp 10.000

4 buah box@1satuan

Rp1.318.900

Berdasarkan rincian di atas harga per satu box adalah Rp329.725. Dengan harga tersebut guru dapat membuat sendiri media pop-up box guna menambah kreativitas guru dengan materi Akuntansi yang lain. Media ini berbahan dasar akrilik sehingga tahan lama apabila digunakan berulang-ulang di dalam kelas. Jika guru akan membuat media pop-up box dengan materi Akuntansi lain, guru harus membuat dengan bahan dasar yang lebih tahan lama dengan harga yang lebih murah lagi.

Dari pembuatan produk tersebut selanjutnya dilakukan validasi oleh beberapa ahli, yaitu:

a. Ahli materi

Validasi ahli materi dilakukan oleh dosen jurusan Akuntansi FE UNY. Berikut adalah hasil penilaian ahli materi.

Tabel 4. Hasil Penilaian Ahli Materi

\begin{tabular}{|c|c|c|c|c|c|}
\hline No & $\begin{array}{c}\text { Aspek } \\
\text { Peni- } \\
\text { laian }\end{array}$ & $\begin{array}{c}\text { Jum- } \\
\text { lah } \\
\text { Skor }\end{array}$ & $\begin{array}{c}\text { Rata } \\
\text { rata }\end{array}$ & $\begin{array}{c}\text { Per- } \\
\text { sentase } \\
(\%)\end{array}$ & $\begin{array}{c}\text { Ka- } \\
\text { tegori }\end{array}$ \\
\hline 1 & $\begin{array}{l}\text { Aspek } \\
\text { pem- } \\
\text { belajar } \\
\text { an }\end{array}$ & 58 & 4,46 & $89,23 \%$ & $\begin{array}{l}\text { Sangat } \\
\text { Layak }\end{array}$ \\
\hline 2 & $\begin{array}{l}\text { Aspek } \\
\text { bahasa }\end{array}$ & 10 & 5,00 & $100 \%$ & $\begin{array}{l}\text { Sangat } \\
\text { Layak }\end{array}$ \\
\hline 3 & $\begin{array}{l}\text { Aspek } \\
\text { Keter- } \\
\text { laksan } \\
\text { aan }\end{array}$ & 18 & 4,50 & $90 \%$ & $\begin{array}{l}\text { Sangat } \\
\text { Layak }\end{array}$ \\
\hline \multicolumn{2}{|c|}{ Total } & 86 & 4,65 & $90,53 \%$ & $\begin{array}{l}\text { Sangat } \\
\text { Layak }\end{array}$ \\
\hline
\end{tabular}

b. Ahli media

Validasi ahli media dilakukan oleh dosen jurusan Pendidikan Akuntansi FE. Berikut adalah hasil penilaian ahli media.

Tabel 5. Hasil Penilaian Ahli Media

\begin{tabular}{|c|c|c|c|c|c|}
\hline No & $\begin{array}{c}\text { Aspek } \\
\text { Penila } \\
\text { ian }\end{array}$ & $\begin{array}{c}\text { Juml } \\
\text { ah } \\
\text { Skor }\end{array}$ & $\begin{array}{c}\text { Rata } \\
\text { rata }\end{array}$ & $\begin{array}{c}\text { Perse } \\
\text { ntase } \\
(\%)\end{array}$ & $\begin{array}{c}\text { Kate- } \\
\text { gori }\end{array}$ \\
\hline
\end{tabular}


Jurnal Pendidikan Akuntansi Indonesia, Vol. XVII, No. 1, Tahun 2019

Denisa Nugrah Anggraeni \& Sukirno

$16-30$

\begin{tabular}{|c|l|c|c|c|c|}
\hline 1 & $\begin{array}{l}\text { Aspek } \\
\text { Rekay } \\
\text { asa } \\
\text { Media }\end{array}$ & 22 & 4,40 & $88 \%$ & $\begin{array}{c}\text { Sa- } \\
\text { ngat } \\
\text { Layak }\end{array}$ \\
\hline 2 & $\begin{array}{l}\text { Aspek } \\
\text { Komu } \\
\text { nikasi } \\
\text { Visual }\end{array}$ & 41 & 4,56 & $\begin{array}{c}91,11 \\
\%\end{array}$ & $\begin{array}{c}\text { Sa- } \\
\text { ngat } \\
\text { Layak }\end{array}$ \\
\hline 3 & $\begin{array}{l}\text { Aspek } \\
\text { bahasa }\end{array}$ & 10 & 5,00 & $100 \%$ & $\begin{array}{c}\text { Sa- } \\
\text { ngat } \\
\text { Layak }\end{array}$ \\
\hline \multicolumn{2}{|c|}{ Total } & 73 & 4,65 & $\begin{array}{c}91,25 \\
\%\end{array}$ & $\begin{array}{c}\text { Sa- } \\
\text { ngat } \\
\text { Layak }\end{array}$ \\
\hline
\end{tabular}

c. Praktisi pembelajaran akuntansi Validasi

praktisi

pembelajaran akuntansi dilakukan oleh guru komputer akuntansi SMKN 1 Bawang Banjarnegara. Berikut adalah hasil penilaian praktisi pembelajaran Akuntansi.

\section{Tabel 6. Hasil Penilaian Praktisi Pembelajaran}

Akuntansi

\begin{tabular}{|c|l|c|c|c|c|}
\hline No & $\begin{array}{c}\text { Aspek } \\
\text { Penilai } \\
\text { an }\end{array}$ & $\begin{array}{c}\text { Jum- } \\
\text { lah } \\
\text { Skor }\end{array}$ & $\begin{array}{c}\text { Rata- } \\
\text { rata }\end{array}$ & $\begin{array}{c}\text { Per- } \\
\text { sentase } \\
(\%)\end{array}$ & $\begin{array}{c}\text { Kate } \\
\text { gori }\end{array}$ \\
\hline 1 & $\begin{array}{l}\text { Aspek } \\
\text { Rekaya } \\
\text { sa } \\
\text { Media }\end{array}$ & 18 & 4,50 & $90 \%$ & $\begin{array}{c}\text { Sang } \\
\text { at } \\
\text { Layak }\end{array}$ \\
\hline 3 & $\begin{array}{l}\text { Aspek } \\
\text { Pembel } \\
\text {-ajaran }\end{array}$ & 50 & 4,55 & $90,91 \%$ & $\begin{array}{c}\text { Sang } \\
\text { at } \\
\text { Layak }\end{array}$ \\
\hline 4 & $\begin{array}{l}\text { Aspek } \\
\text { Komun } \\
\text { i-katif }\end{array}$ & 20 & 4,00 & $100 \%$ & $\begin{array}{c}\text { Sang } \\
\text { at } \\
\text { Layak }\end{array}$ \\
\hline 5 & $\begin{array}{l}\text { Aspek } \\
\text { Bahasa }\end{array}$ & 8 & 4,00 & $80 \%$ & Layak \\
\hline \multicolumn{7}{|c|}{ Total } & 88 & 4,35 & $83,81 \%$ & $\begin{array}{c}\text { Sang } \\
\text { at } \\
\text { Layak }\end{array}$ \\
\hline
\end{tabular}

Gambar 2. Media pop-up box tampak

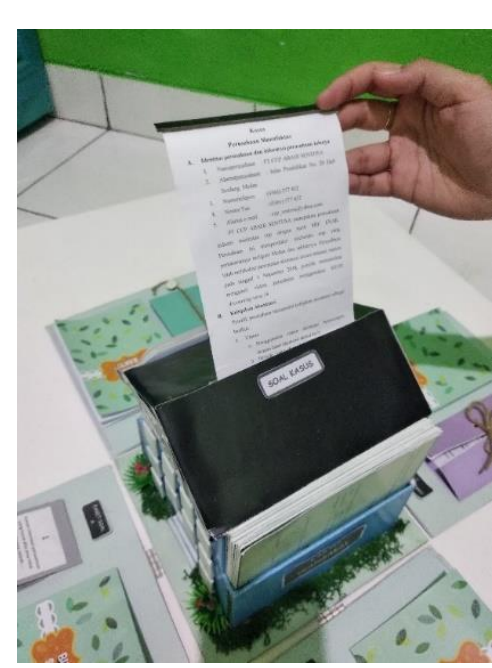

Gambar 3. Soal kasus dalam pop-up box

Adapun gambar komponen dari media Pop-up Box Simulasi MYOB Accounting adalah sebagai berikut:

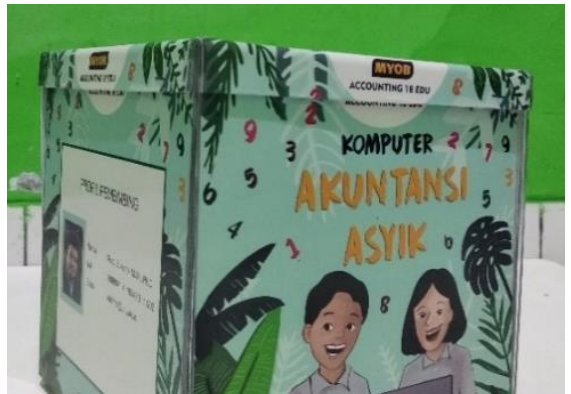

Gambar 1. Media pop-up box tampak luar

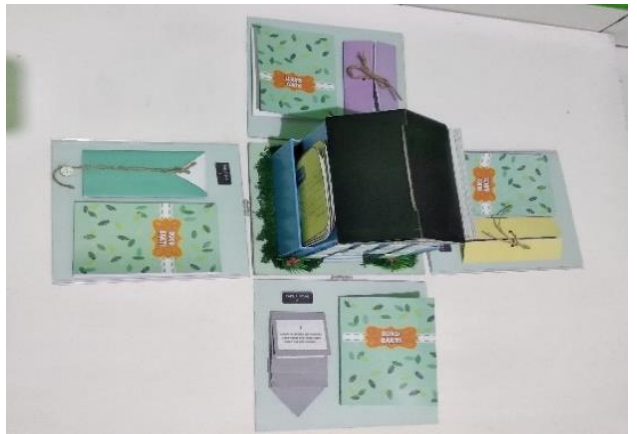

\section{dalam}

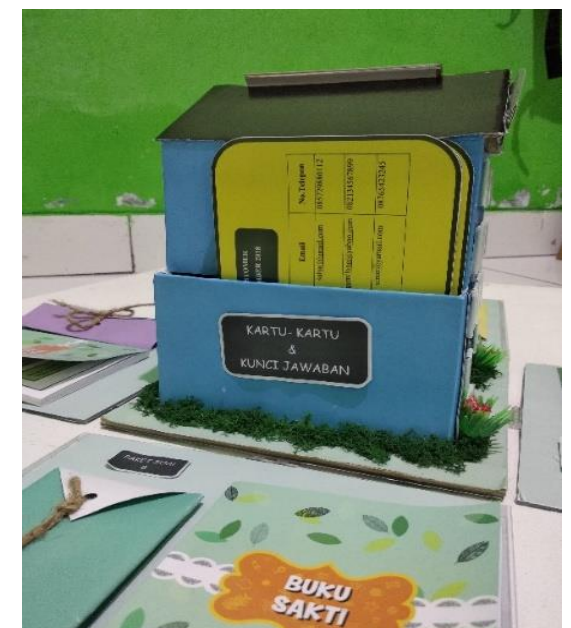




\section{Gambar 4. Kartu pelengkap transaksi}

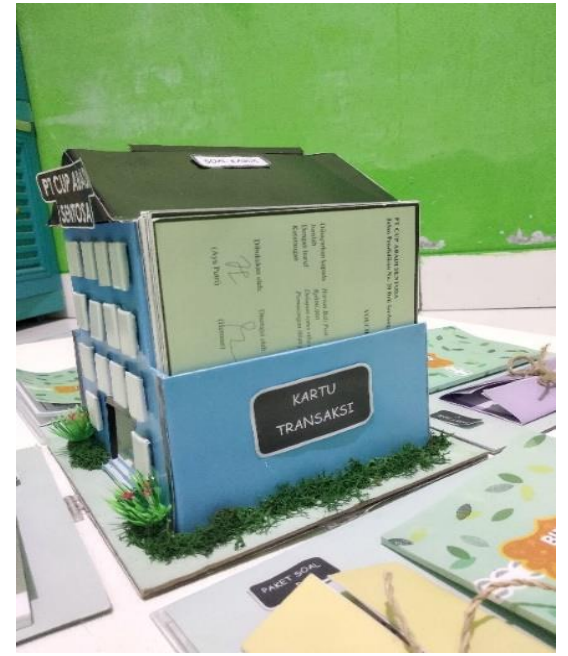

Gambar 5. Kartu transaksi

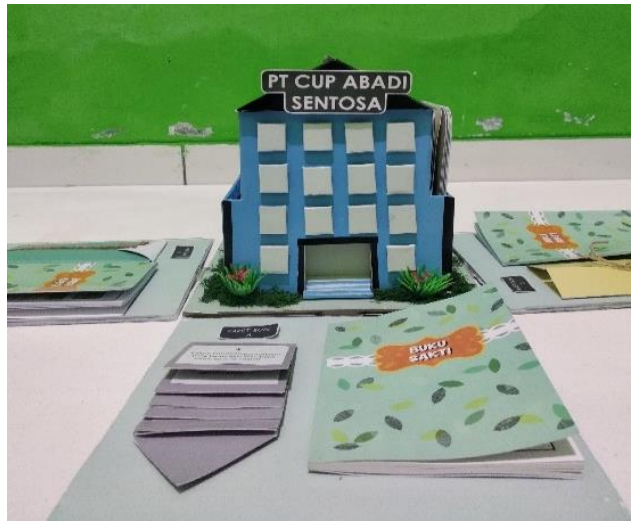

Gambar 6. Miniatur perusahaan

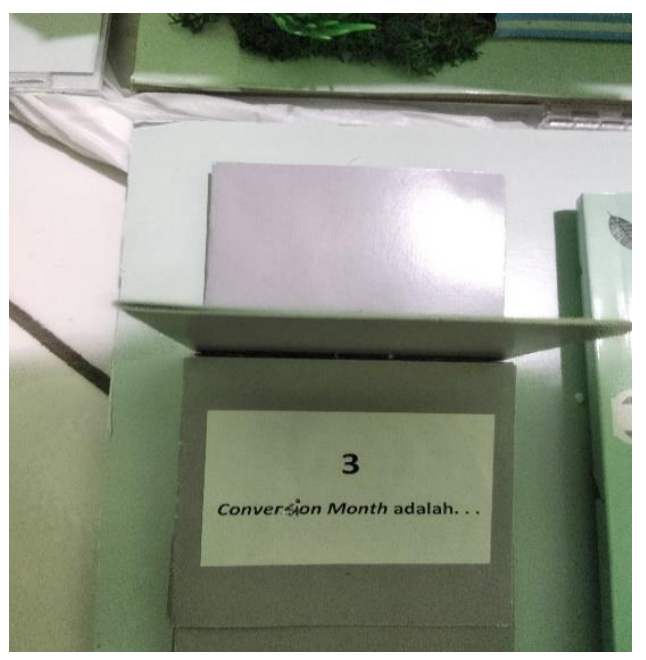

Gambar 7. Contoh pengemasan soal teori

Berdasarkan penilaian yang dilakukan oleh ahli materi, ahli media, dan praktisi pembelajaran Akuntansi. Peneliti mendapatkan saran yang harus diperbaiki terkait dengan media yang dikembangkan yaitu:

a. Revisi ahli media

1) Kurangnya tulisan versi Accounting 18 Edu dalam cover box.

2) Untuk judul Petunjuk Penggunaan Pop-up Box menggunakan huruf kapital.

3) Tidak ada bingkai pembatas antara desain cover box dengan tulisan

4) Bentuk bingkai foto peneliti dalam cover box berbeda dengan bingkai foto pembimbing

5) Ukuran font riwayat peneliti terlalu kecil

6) Penulisan dalam kartu-kartu terlalu dekat dengan kotak

7) Perekat di buku sakti terlalu kecil

8) Kurangnya atribut media sebagai pemberi informasi untuk memperjelas tujuan dari isi media

9) Terdapat istilah yang salah yakni Convention Month

b. Revisi praktisi pembelajaran Akuntansi

Saran yang diberikan oleh praktisi pembelajaran adalah penggunaan warna yang berbeda untuk setiap masing-masing kelompok transaksi.

4. Tahap Implementasi (Implementation) 
Tahap implementasi dilakukan dalam dua tahap yaitu uji coba kelompok kecil dan uji lapangan. Pada uji coba kelompok kecil dilakukan pada 16 siswa dari kelas XII Akuntansi 3 dan uji lapangan dilakukan pada kelas XII Akuntansi 1 yang terdiri dari 36 siswa. Selanjutnya, dilakukan uji lapangan pada kelas XII Akuntansi 1 yang terdiri dari 36 siswa. Berikut adalah hasil penilaian uji lapangan.

5. Tahap Evaluasi (Evaluation)

a. Perbandingan tahapan uji coba

Uji coba ini dilakukan melalui dua tahap yakni uji coba kelompok kecil dan uji coba lapangan yang telah dihitung tingkat kualitas kelayakan media. Berikut adalah tabel perbandingan hasil perhitungan kelayakan media.

Tabel 7. Perbandingan Tahapan Uji Coba

\begin{tabular}{|c|c|c|c|}
\hline \multirow[t]{2}{*}{ No } & \multirow[t]{2}{*}{ Aspek } & \multicolumn{2}{|c|}{ Uji Coba } \\
\hline & & $\begin{array}{l}\text { Kelompok } \\
\text { Kecil }\end{array}$ & Lapangan \\
\hline 1 & $\begin{array}{l}\text { Aspek } \\
\text { Rekayasa } \\
\text { Media }\end{array}$ & 4,78 & 4,80 \\
\hline 2 & $\begin{array}{l}\text { Aspek } \\
\text { Pembelajar- } \\
\text { an }\end{array}$ & 4,73 & 4,78 \\
\hline 3 & $\begin{array}{l}\text { Aspek } \\
\text { Komuni-kasi } \\
\text { Visual }\end{array}$ & 4,73 & 4,68 \\
\hline 4 & $\begin{array}{l}\text { Aspek } \\
\text { Bahasa }\end{array}$ & 4,69 & 4,56 \\
\hline & Jumlah & 18,93 & 18,82 \\
\hline
\end{tabular}

b. Analisis Kelayakan Media Pembelajaran

Penilaian kelayakan media pembelajaran diperoleh berdasarkan ahli materi, ahli media, praktisi pembelajaran akuntansi dan siswa

Tabel 8. Kelayakan Media pada Setiap Tahapan

\begin{tabular}{|c|c|c|c|c|c|}
\hline $\begin{array}{c}\text { N } \\
\text { o }\end{array}$ & $\begin{array}{c}\text { Tahap- } \\
\text { an Peni- } \\
\text { laian }\end{array}$ & $\begin{array}{c}\text { Jum- } \\
\text { lah } \\
\text { Skor }\end{array}$ & $\begin{array}{c}\text { Re- } \\
\text { rata } \\
\text { Skor }\end{array}$ & $\begin{array}{c}\text { Per- } \\
\text { senta } \\
\text { se } \\
(\%)\end{array}$ & $\begin{array}{c}\text { Krite } \\
\text { ria }\end{array}$ \\
\hline
\end{tabular}

\begin{tabular}{|c|c|c|c|c|c|}
\hline 1 & $\begin{array}{c}\text { Ahli } \\
\text { Materi }\end{array}$ & 86 & 4,65 & 90,53 & $\begin{array}{c}\text { Sa-ngat } \\
\text { Layak }\end{array}$ \\
\hline 2 & $\begin{array}{c}\text { Ahli } \\
\text { Media }\end{array}$ & 73 & 4,65 & 91,25 & $\begin{array}{c}\text { Sa-ngat } \\
\text { Layak }\end{array}$ \\
\hline 3 & $\begin{array}{c}\text { Praktisi } \\
\text { Pem- } \\
\text { belajar- } \\
\text { an }\end{array}$ & 88 & 4,35 & 83,81 & $\begin{array}{c}\text { Sa-ngat } \\
\text { Layak }\end{array}$ \\
\hline $\begin{array}{c}\text { Uji Coba } \\
\text { Kelom- } \\
\text { pok } \\
\text { Kecil }\end{array}$ & 1667 & 4,74 & 94,75 & $\begin{array}{c}\text { Sa-ngat } \\
\text { Layak }\end{array}$ \\
\hline 5 & $\begin{array}{c}\text { Uji Coba } \\
\text { Lapa- } \\
\text { ngan }\end{array}$ & 3749 & 4,73 & 94,67 & $\begin{array}{c}\text { Sa-ngat } \\
\text { Layak }\end{array}$ \\
\hline \multicolumn{2}{|c|}{$\begin{array}{c}\text { Rerata } \\
\text { Relat }\end{array}$} & 1132,6 & 4,62 & $91 \%$ & $\begin{array}{c}\text { Sangat } \\
\text { Layak }\end{array}$ \\
\hline
\end{tabular}

\section{Penilaian Kelayakan Media Pop-up Box} Simulasi MYOB Accounting

Hasil penilaian dari masing-masing ahli terhadap media pembelajaran Pop-up Box Simulasi $M Y O B$ Accounting yang telah peneliti kembangkan, diperoleh rekapitulasi penilaian keseluruhan ahli adalah sebagai berikut.

Tabel 9. Rekapitulasi

Penilaian

Keseluruhan Ahli

\begin{tabular}{|c|c|c|c|c|c|c|c|}
\hline $\begin{array}{l}\mathbf{N} \\
\mathbf{0}\end{array}$ & Aspek & $\begin{array}{l}\text { Ahli } \\
\text { Ma- } \\
\text { teri }\end{array}$ & $\begin{array}{c}\text { Ahli } \\
\text { Me- } \\
\text { dia }\end{array}$ & $\begin{array}{c}\text { Prak- } \\
\text { tisi } \\
\text { Pem- } \\
\text { bela- } \\
\text { jaran }\end{array}$ & $\begin{array}{c}\text { Rata } \\
\text { rata }\end{array}$ & $\begin{array}{l}\text { Per- } \\
\text { sen- } \\
\text { tase }\end{array}$ & $\begin{array}{c}\text { Ka- } \\
\text { te- } \\
\text { gori }\end{array}$ \\
\hline 1 & $\begin{array}{l}\text { Aspek } \\
\text { Pem- } \\
\text { bela- } \\
\text { jaran }\end{array}$ & 4,46 & & 4,55 & 4,51 & $\begin{array}{c}90,2 \\
0 \%\end{array}$ & SL \\
\hline 2 & $\begin{array}{c}\text { Aspek } \\
\text { Baha- } \\
\text { sa }\end{array}$ & 5,00 & 5,00 & 4,00 & 4,67 & $\begin{array}{c}93,4 \\
0 \%\end{array}$ & SL \\
\hline 3 & $\begin{array}{c}\text { Aspek } \\
\text { Keter- } \\
\text { laksa- } \\
\text { naan } \\
\end{array}$ & 4,50 & & & 4,50 & $90 \%$ & SL \\
\hline 4 & $\begin{array}{c}\text { Aspek } \\
\text { Reka- } \\
\text { yasa } \\
\text { Media }\end{array}$ & & 4,40 & 4,50 & 4,45 & $89 \%$ & SL \\
\hline 5 & $\begin{array}{c}\text { Aspek } \\
\text { Ko- } \\
\text { muni- } \\
\text { kasi } \\
\text { Visual }\end{array}$ & & 4,56 & & 4,56 & $\begin{array}{c}91,2 \\
0 \%\end{array}$ & SL \\
\hline 6 & $\begin{array}{c}\text { Aspek } \\
\text { Ko- } \\
\text { muni- } \\
\text { katif }\end{array}$ & & & 5,00 & 5,00 & $\begin{array}{c}100 \\
\%\end{array}$ & SL \\
\hline
\end{tabular}


Jurnal Pendidikan Akuntansi Indonesia, Vol. XVII, No. 1, Tahun 2019

Denisa Nugrah Anggraeni \& Sukirno

$16-30$

\begin{tabular}{|c|c|c|c|c|c|c|c|}
\hline $\begin{array}{c}\text { N } \\
\text { o }\end{array}$ & Aspek & $\begin{array}{c}\text { Ahli } \\
\text { Ma- } \\
\text { teri }\end{array}$ & $\begin{array}{c}\text { Ahli } \\
\text { Me- } \\
\text { dia }\end{array}$ & $\begin{array}{c}\text { Prak- } \\
\text { tisi } \\
\text { Pem- } \\
\text { bela- } \\
\text { jaran }\end{array}$ & $\begin{array}{c}\text { Rata } \\
\text { rata }\end{array}$ & $\begin{array}{c}\text { Per- } \\
\text { sen- } \\
\text { tase }\end{array}$ & $\begin{array}{c}\text { Ka- } \\
\text { te- } \\
\text { gori }\end{array}$ \\
\hline \multicolumn{3}{|c|}{ Rata-rata keseluruhan } & 4,61 & $\begin{array}{c}92,2 \\
0 \%\end{array}$ & SL \\
\hline
\end{tabular}

Penilaian Siswa Terhadap Implementasi Pengembangan Media Pembelajaran Pop-up Box Simulasi MYOB Accounting

1. Uji Coba Kelompok Kecil

Tabel 10. Hasil Penilaian Uji Coba Kelompok Kecil

\begin{tabular}{|c|l|c|c|c|c|}
\hline No & Aspek & $\begin{array}{c}\text { Jum- } \\
\text { lah } \\
\text { Skor }\end{array}$ & $\begin{array}{c}\text { Rata- } \\
\text { rata }\end{array}$ & $\begin{array}{c}\text { Per- } \\
\text { senta- } \\
\text { se } \\
(\%)\end{array}$ & $\begin{array}{c}\text { Kate- } \\
\text { gori }\end{array}$ \\
\hline 1 & $\begin{array}{l}\text { Aspek } \\
\text { Rekaya } \\
\text { sa } \\
\text { Media }\end{array}$ & 382 & 4,78 & 95,50 & $\begin{array}{c}\text { Sangat } \\
\text { Layak }\end{array}$ \\
\hline 2 & $\begin{array}{l}\text { Aspek } \\
\text { Pembel } \\
\text { ajaran }\end{array}$ & 605 & 4,73 & 94,53 & $\begin{array}{l}\text { Sangat } \\
\text { Layak }\end{array}$ \\
\hline 3 & $\begin{array}{l}\text { Aspek } \\
\text { Komu } \\
\text { nikasi } \\
\text { Visual }\end{array}$ & 530 & 4,73 & 94,64 & $\begin{array}{l}\text { Sangat } \\
\text { Layak }\end{array}$ \\
\hline 4 & $\begin{array}{l}\text { Aspek } \\
\text { Bahasa }\end{array}$ & 150 & 4,69 & 93,75 & $\begin{array}{l}\text { Sangat } \\
\text { Layak }\end{array}$ \\
\hline \multicolumn{7}{|l|}{ Rata-rata } \\
Keseluruhan & 4,74 & 94,72 & $\begin{array}{l}\text { Sangat } \\
\text { Layak }\end{array}$ \\
\hline
\end{tabular}

2. Uji Lapangan

Tabel 11. Hasil Penilaian Uji Lapangan

\begin{tabular}{|c|l|c|c|c|c|}
\hline $\begin{array}{c}\text { N } \\
\mathbf{0}\end{array}$ & Aspek & $\begin{array}{c}\text { Jum- } \\
\text { lah } \\
\text { Skor }\end{array}$ & $\begin{array}{c}\text { Rata } \\
\text { rata }\end{array}$ & $\begin{array}{c}\text { Per- } \\
\text { sen- } \\
\text { tase } \\
\mathbf{( \% )}\end{array}$ & $\begin{array}{c}\text { Kate- } \\
\text { gori }\end{array}$ \\
\hline 1 & $\begin{array}{l}\text { Aspek } \\
\text { Rekaya- } \\
\text { sa } \\
\text { Media }\end{array}$ & 865 & 4,81 & 96,11 & $\begin{array}{c}\text { Sangat } \\
\text { Layak }\end{array}$ \\
\hline 2 & $\begin{array}{l}\text { Aspek } \\
\text { Pembela } \\
\text {-jaran }\end{array}$ & 1377 & 4,78 & 95,63 & $\begin{array}{l}\text { Sangat } \\
\text { Layak }\end{array}$ \\
\hline 3 & $\begin{array}{l}\text { Aspek } \\
\text { Komuni } \\
\text { kasi } \\
\text { Visual }\end{array}$ & 1179 & 4,68 & 93,57 & $\begin{array}{l}\text { Sangat } \\
\text { Layak }\end{array}$ \\
\hline
\end{tabular}

\begin{tabular}{|c|l|c|c|c|c|}
\hline $\begin{array}{c}\text { N } \\
\text { o }\end{array}$ & Aspek & $\begin{array}{c}\text { Jum- } \\
\text { lah } \\
\text { Skor }\end{array}$ & $\begin{array}{c}\text { Rata } \\
\text { rata }\end{array}$ & $\begin{array}{c}\text { Per- } \\
\text { sen- } \\
\text { tase } \\
(\boldsymbol{\%})\end{array}$ & $\begin{array}{c}\text { Kate- } \\
\text { gori }\end{array}$ \\
\hline 4 & $\begin{array}{l}\text { Aspek } \\
\text { Bahasa }\end{array}$ & 328 & 4,56 & 91,11 & $\begin{array}{c}\text { Sangat } \\
\text { Layak }\end{array}$ \\
\hline \multicolumn{2}{|c|}{ Rata-rata Keseluruhan } & 4,73 & 94,67 & $\begin{array}{l}\text { Sangat } \\
\text { Layak }\end{array}$ \\
\hline
\end{tabular}

\section{Pembahasan Pengembangan Media Pembelajaran Pop-up Box Simulasi MYOB Accounting}

Penelitian yang telah dilakukan membuktikan bahwa pengembangan media pembelajaran Pop-up Box Simulasi $M Y O B$ Accounting layak digunakan siswa sebagai media pembelajaran. Hal ini sejalan dengan penelitian yang dilakukan oleh Scolastika Mariani, dkk (2014) yang berjudul "The Effectiveness of Learning by PBL Assisted Mathematics Pop-Up Book Againts The Spatial Ability in Grade VIII on Geometry Subject Matter" yang menunjukkan bahwa pop-up apabila digunakan melalui konsep penjelasan, konsep latihan, dan dilakukan secara berkelompok hasilnya sangat bagus. Selanjutnya, penelitian yang dilakukan oleh Septi Mahayani (2015) juga melakukan penelitian yang sejalan dengan hasil penelitian bahwa kelebihan menggunakan media kotak pop-up dapat memperjelas masalah dalam bidang apa saja. Penelitian ini sejalan dengan teori yang dikemukakan oleh Rob Ives dalam Helda Arina Simatupang (2016) yang menyatakan bahwa pop-up memberikan kemampuan gambar untuk bergerak yang berasal dari kertas yang dilipat, digulung, didorong atau dibalik. Pop-up yang dikembangkan oleh peneliti juga memiliki kemampuan untuk ditarik atau didorong.

Pengembangan media pembelajaran Pop-up Box Simulasi MYOB Accounting menggunakan lima tahapan model pengembangan ADDIE yakni dimulai dari tahap analysis terhadap kebutuhan siswa dan analisis kompetensi inti dan kompetensi dasar yang digunakan di SMK Negeri 1 
Bawang Banjarnegara. pada tahap design, peneliti merancang konsep media yang meliputi pembuatan konsep desain media pembelajaran, penyusunan materi, soal, kunci jawaban dan petunjuk penggunaan media. Tahap selanjutnya adalah development, pembuatan media pembelajaran Pop-up Box Simulasi $M Y O B$ Accounting dan dilakukan penilaian kelayakan media oleh ahli materi, ahli media, serta praktisi pembelajaran Akuntansi. Tahap implementation, media diujicobakan melalui dua tahap yakni uji coba kelompok kecil yang terdiri dari 16 siswa dan uji coba lapangan terdiri dari 36 siswa. Tahap evaluation, pengembangan Media Pembelajaran Pop-up Box Simulasi $M Y O B$ Accounting adalah membandingkan hasil dari seluruh tahapan uji coba dan merekapitulasi hasil dari penilaian kelayakan oleh ahli materi, ahli media, praktisi pembelajaran Akuntansi dan siswa.

\section{Penilaian Kelayakan Media Pop-up Box Simulasi MYOB Accounting}

Kelayakan media pembelajaran dinilai oleh ahli materi materi, ahli media, dan praktisi pembelajaran Akuntansi. Berdasarkan tabel 9 mengenai rekapitulasi penilaian keseluruhan ahli memperoleh persentase penilaian kualitas media pembelajaran sebesar $92,20 \%$ yang terletak pada rentang $81-100 \%$ termasuk dalam kategori Sangat Layak.

\section{Penilaian Siswa Terhadap Implementasi Pengembangan Media Pembelajaran Pop-up Box Simulasi MYOB Accounting}

Media yang dikembangkan dapat dinilai oleh siswa pada tahap implementasi. Berdasarkan tabel 10 mengenai hasil penilaian siswa uji coba kelompok kecil diperoleh persentase kualitas kelayakan media sebesar $94,72 \%$ yang terletak pada rentang 81-100\% termasuk kategori Sangat Layak. Artinya dalam uji coba kelompok kecil di kelas XII Akuntansi 3 media pembelajaran Pop-up Box Simulasi $M Y O B$ Accounting sudah memenuhi kebutuhan siswa yang membuat siswa tertarik untuk mencoba menggunakan media Pop-up Box Simulasi $M Y O B$ Accounting, sehingga media tersebut memenuhi syarat untuk diuji coba lapangan.

Berdasarkan tabel 11 mengenai hasil penilaian siswa uji coba lapangan diperoleh persentase kualitas kelayakan media sebesar 94, 67\% yang terletak pada rentang $81-100 \%$ termasuk kategori Sangat Layak. Media Pop-up Box Simulasi MYOB Accounting memiliki kriteria sangat layak digunakan siswa sebagai alternatif media pembelajaran di kelas.

\section{SIMPULAN DAN SARAN Simpulan}

Berdasarkan hasil penelitian dan pembahasan pada Bab IV, maka penelitian dan pengembangan ini dapat disimpulkan bahwa pengembangan media pembelajaran pop-up box simulasi myob accounting melalui lima tahapan yaitu analysis, design, development, implementation, dan evaluation.

Penilaian kelayakan media pembelajaran Pop-up Box Simulasi $M Y O B$ Accounting diketahui berdasarkan penilaian kelayakan dari ahli materi diperoleh persentase kualitas kelayakan media sebesar 90,53\% termasuk dalam kategori Sangat Layak, ahli media diperoleh persentase kualitas kelayakan media sebesar 91,25\% termasuk dalam kategori Sangat Layak, praktisi pembelajaran Akuntansi diperoleh persentase kualitas kelayakan media sebesar $83,81 \%$ termasuk dalam kategori Sangat Layak.

Penilaian siswa terhadap media pembelajaran Pop-up Box Simulasi $M Y O B$ Accounting diketahui berdasarkan uji coba kelompok kecil diperoleh persentase kualitas kelayakan media sebesar 94,72\% termasuk dalam kategori Sangat Layak dan berdasarkan uji coba lapangan diperoleh persentase kualitas kelayakan media sebesar 
94,67\% termasuk dalam kategori Sangat Layak. Dengan demikian dilihat dari penilaian siswa Media Pembelajaran Pop-up Box Simulasi MYOB Accounting layak digunakan sebagai media pembelajaran.

\section{Saran}

Berdasarkan penelitian pengembangan kualitas media dan keterbatasan pengembangan yang telah dijelaskan, peneliti dapat memberikan saran pemanfaatan dan pengembangan media lebih lanjut yaitu bagi siswa, media pembelajaran Pop-up Box Simulasi $M Y O B$ Accounting dapat digunakan siswa dalam pembelajaran dikelas dan siswa membaca kembali catatan tentang mata pelajaran Komputer Akuntansi sembari menunggu giliran penggunaan media Pop-up Box Simulasi MYOB Accounting.

Bagi guru media pembelajaran Pop-up Box Simulasi MYOB Accounting dapat digunakan sebagai penunjang pembelajaran pada mata pelajaran Komputer Akuntansi dan mata pelajaran lainnya, guru memberikan tugas kepada siswa yang menunggu giliran dalam menggunakan media pembelajaran Pop-up Box Simulasi MYOB Accounting untuk membaca kembali catatan tentang mata pelajaran Komputer Akuntansi sebelum menggunakan media pembelajaran Pop-up Box, dan guru dapat melakukan produksi masal media Pop-up Box Simulasi $M Y O B$ Accounting, sehingga bisa mendapatkan media pembelajaran $P o p$ up Box Simulasi MYOB Accounting dengan harga yang lebih murah tanpa menurunkan kualitas media tersebut.

Bagi sekolah, media pembelajaran Popup Box Simulasi MYOB Accounting digunakan pada mata pelajaran Komputer Akuntansi dan dapat diperbanyak guna menambah kreatifitas.

Bagi peneliti selanjutnya, perlu adanya pengembangan media pembelajaran Pop-up Box Simulasi MYOB Accounting lebih lanjut dengan memperhatikan kembali ukuran produk tersebut, peneliti dapat mengembangkan media pembelajaran Popup Box Simulasi MYOB Accounting pada materi akuntansi yang lain, dan peneliti dapat mengembangkan inovasi lagi terhadap media pembelajaran Pop-up Box Simulasi $M Y O B$ Accounting versi terbaru yang lebih unik dan menarik.

\section{DAFTAR PUSTAKA}

Arsyad, Azhar (2015). Media Pembelajaran. Jakarta: PT. Raja Grafindo Persada.

Dwikoranto. (2009). Meningkatkan Kompetensi Guru Matematika Dan IPA SMP Melalui Kegiatan Lesson Study. FMIPA UNESA.

Ernawati I \& Sukardiyono T. (2017). Uji Kelayakan Media Pembelajaran Interaktif pada Mata Pelajaran Administrasi Server. Elinvo (Electronics, Informatics, and Vocational Education). Vol 2, No.2. 204-210.

Mulyatiningsih, Endang. (2012). Metode Penelitian Terapan Bidang Pendidikan. Bandung: Penerbit Alfabeta.

Mariani, Scolastika dkk (2014). The Effectiveness of Learning by $P B L$ Assisted Mathematics Pop-ip Book Againts The Spatial Ability in Grade VIII on Geometry Subject Matter. International Journal of Education and Research. Vol 2, No. 8, $531-548$.

Mahayani, Septi (2017). Pengembangan Media Pembelajaran Berupa Kotak Pop-up Berbasis Problem Solving Untuk Menunjang Pembelajaran Fisika Materi Cahaya Dan Alat-alat Optik. Skripsi. IAIN Raden Intan Lampung.

Maulidah, Hikmatul. (2011). Pengaruh Penguasaan Kosa Kata Bahasa Inggris 
Dalam Akuntansi, Dasar Komputer, Dan Akuntansi Dasar Terhadap Prestasi Belajar Komputer Akuntansi $M Y O B$ Siswa Kelas XI Kompetensi Keahlian Akuntansi SMK Negeri 2 Tegal Tahun Ajaran 2010/2011. Skripsi: UNNES.

Numtahanah, Nurotun. (2014). Penggunaan Media Visual Dalam Pembelajaran PAI. Jurnal Studi Keislaman. Vol 4, No. 1, 92-104.

Octoria, Dini. (2015). Peran Guru Akuntansi Dalam Mewujudkan Empat Pilar Pembelajaran Melalui Accounting Simulation. Prosiding Seminar Nasional Pendidikan Akuntansi dan Keuangan.

Sadiman, A S. (2014). Media Pendidikan Pengertian, Pengembangan, dan Pemanfaatanya. Jakarta: PT Raja Grafindo Persada.

Simatupang, H.A. (2016). Pengembangan Media Pop-up Pada Materi Organisasi Kehidupan Untuk Meningkatkan Motivasi Dan Hasil Belajar Peserta Didik SMP Kelas VII. Skripsi: UNY.

Sugiyono. (2016). Metode Penelitian Kuantitatif, Kualitatif dan $R \& D$. Bandung: CV Alfabeta.

Sudjana N dan Rivai A. (2011). Media Pengajaran. Bandung: Sinar Baru Algesindo.

Widoyoko, E.P. (2012). Teknik Penyusunan Instrumen Penelitian. Yogyakarta: Pustaka Belajar. 